\title{
Arkitektur og teknologi som avgrensar pleietrengjande sin tilgang til WC
}

\author{
Ein praxeologisk analyse av korleis konstruksjonar av private bustader og \\ sjukeheimar strukturerer pleietrengjande sine toalettpraktikkar.
}

\author{
Jeanne Helene Boge \\ Professor i Sykepleievitenskap, Institutt for helse- og omsorgsvitskap, Høgskulen på Vestlandet (HVL)
}

\begin{abstract}
This is an article on how architecture and technology in private homes and Nursing Homes structure disabled's toilet practices. The analysis shows that the design of private houses can prohibit disabled from using the WC. Some of them have to sleep in the sitting room and use a toilet chair there. That means that practices that usually take place in private parts of a home, like sleeping rooms and bath/WC, take place in official parts of the home. Such changes may contradict the practical sense of disabled and their families.

In Norwegian nursing homes, the residents usually have their own room and bath/WC. The toilet practices are carried out in such private parts of the institution. But the construction of the units often makes it impossible for disabled to use the WC if they cannot stand/walk.

If one look at contemporary Norwegian private houses and Nursing Home units in the light of Bourdieu's theory on the premodern Kabylien house, there is av homology between the feminine, lower part of the Kabylien house and the bath/WC/sleeping room in contemporary Norwegian private homes and nursing homes, because the biological body is handled in such parts of the building. In contemporary Norway, as in the Kabylien house, such biological practices are considered feminine, they have a low status and they are invisible outside the house. Since the practices are not articulated in public parts of the society, Architects and Engineers can lack information on how architecture and technical solutions can affect disabled's toilet practices. Therefor it is likely that they
\end{abstract}


continue constructing private homes and Nursing Homes in accordance with the practical buildingsense they have incorporated. But by constructing private homes were disabled has to sleep and carry out their toilet practices in the sitting room, and in constructing Nursing Homes that prohibit disabled from using the WC, Architects and Engineers carry out symbolic violence.

Keywords: WC, toilet, practice, architecture, sanitary technology, ceiling mounted lifts, Nursing Home, home nursing. Bourdieu, praxeology, the Kabyle house, practical sense, symbolic violence

\section{Samandrag}

Denne artikkelen er ein analyse av korleis arkitektur og teknologi i private bustader og sjukeheimar, strukturerer toalettpraktikkane til pleietrengjande. Analysen viser at private bustader kan vere utforma slik at pleietrengjande må sove i stova og gjere frå seg på ein toalettstol der. Dette inneber at gjeremål som vanlegvis finn stad i private delar av bustaden som bad/WC og soverom, vert flytta til stova, den offentlege delen av bustaden. Slike endringar kan stride imot pleietrengjande og deira familie sin praktiske sans.

I norske sjukeheimar bur dei pleietrengjande vanlegvis i eige rom med tilhøyrande bad/WC. I denne private delen av institusjonen finn toalettpraktikkane stad. Bueiningane er konstruerte slik at pleietrengjande som ikkje kan stå på føtene ofte heller ikkje kan bruke WC.

Om ein ser på den norske private notids-bustaden og notids-bueininga i sjukeheimar i lys av det $f ø r$-moderne kabylske huset som var delt i ein $\varnothing v r e$ og ein nedre del, er bad/WC og soverom i notidsbustaden og notids-bueininga i sjukeheimen på mange vis homolog til den feminine, lågaste delen av det kabylske huset, fordi det er i slike delar av bustaden ein handterer den biologiske kroppen. Gjeremåla som fann stad i den lågaste delen av det kabylske huset vart rekna for feminine, dei hadde låg status og var usynlege utanfor bustaden. Den same låge statusen har arbeidet med toalettpraktikkar i helsevesenet. Slikt arbeider er sjeldan artikulert og problematisert i det offentlege rommet, så arkitektar og ingeniørar kan mangle informasjon om korleis arkitektur kan fremje/hemme toalettpraktikkar til sjuke og pleietrengjande. Dermed er det sannsynleg at dei held fram med å konstruere private og offentlege bygg som er i pakt med den praktiske byggsansen som dei har inkorporert. Når dei konstruerer private bygg slik at pleietrengjande må gjere frå seg i stova og konstruerer sjukeheimar som forhindrar dei mest pleietrengjande i å bruke WC, utøver dei samstundes symbolsk vald.

Nøkkelord: WC, toalett, praktikk, arkitektur, sanitær teknologi, takheiser, sjukehjem, heimesjukepleie, Bourdieu, praxeologi, det kabylske huset, praktisk sans, symbolsk vald 


\section{Innleiing}

Formålet med denne teksten er å forstå og forklare korleis arkitektonisk og teknisk utforming av private bustader og sjukeheimar kan strukturere pleietrengjande sine toalettpraktikkar. Praktikk er ei form for umedviten miming av det familie, vennar, kollegaar og andre i det sosiale rommet gjer og seier (Callewaert 1997, s. 13 - 26).

I studien har eg gått ut i frå at private og offentlege husvære er delt i offentlege og private soner og forventingar om at toalettpraktikkar finn stad i private soner. Desse forventingane er hovudsakleg funderte i den franske sosiologen Pierre Bourdieu (1996, s. 7-26) sin teori om det kabylske huset. I dette huset står den høgverdige, lyse, maskuline, offentlege delen av huset i motsetnad til den nedre, mørke, feminine delen av huset der den biologiske kroppen vert handtert. Teorien om det kabylske huset er supplert med Bourdieu sin teori om symbolsk vald (Bourdieu, 1996, s. 38-47) og teorien hans om praktisk sans (Callewaert, 1997, s. 13-26). Analysane er såleis gjort i lys av praxeologisk vitskapsteori (Bourdieu, 1998, s. 72-108; Boge, 2021). Det er gjort nærare greie for teoretisk fundering og metodar lenger nede i teksten.

Analysen er delt $\mathrm{i}$ to delar. Del I er ein analyse av korleis arkitektur og teknologi formar tilgangen til WC i private bustader, medan del II er ein analyse av korleis arkitektur og teknologi formar tilgangen til WC i sjukeheimar.

\section{Pleietrengjande som treng hjelp i toalettsituasjonar}

Det kan variere kor ofte personar kvittar seg med urin og avføring, men det er vanleg å late urin fleire gongar i døgnet. Det kan vere lengre intervall mellom avføringar.

Det ser ut for at om lag $90 \%$ av tenestemottakarane i dei norske kommunale pleietenestene treng hjelp i toalettsituasjonar (Boge, 2008, s. 126; Hofseth \& Norvoll, 2003). Nokon fordi dei er ust $\varnothing$ dige, andre fordi dei har lita/inga kraft i armar og føter, manglar kontroll over urin og avføring, ikkje ser, ikkje hugsar kvar WC er eller ikkje hugsar korleis dei skal handtere toalettsituasjonar. Det er spesielt eldre som er utsette for kroppslege utfordringar som må ha hjelp i toalettsituasjonar (Boge, 2020. 3539).

Majoriteten av pleietrengjande i Noreg bur heime og får hjelp av heimesjukepleie og sosiale nettverk som kan vera familie, venar og naboar, men det er uvanleg at familie, venar og naboar hjelper til i samband kroppsvask og -stell. Slikt er det vanlegvis personell i heimesjukepleia som tek seg av (Kristhoff \& Andersen, 2016). Men det er ikkje alle som får den hjelpa dei treng. I norske aviser kan me lese om ein norsk 36 år gamal, multihandikappa, heimebuande rullestolbrukar som berre fekk hjelp av heimesjukepleiar til å koma seg på toalettet tre-fire gongar i veka. Hen var ofte forstoppa (obstipert) og innlagt på sjukehus med store smerter (Glatved-Prahl, 2015). Danske og norske medium viser at heller ikkje sjukeheimsbebuarar får den hjelp dei treng i toalettsituasjonar. Dei kan få beskjed om å gjere frå seg i bleier i staden for på WC (Haagensen, 2018; Kjær, 2019). Rapportar frå fleire vestlege land viser at pasientar i sjukehus også kan bli verande i våte bleier og ekskrement i timesvis (Darbyshire, Ralph \& Caudle, 2015). Lite hjelp i toalettsituasjonar er noko av det pasientar på engelske sjukehus klagar mest på (Dean, 2012). I ei spørjeundersøking som omfatta 1640 sjukepleiarar som arbeidde i dei norske kommunale pleietenestene, meinte om lag $40 \%$ at dei pleietrengjande kunne klart seg utan bleier om bemanninga hadde vore betre (Ruud \& Dommerud, 2015).

\section{Avgrensing}

Sjølv om analysar av relasjonar mellom bemanningspolitikk og pleietrengjande sine toalettpraktikkar er høgst relevante, er denne artikkelen avgrensa til analysar av tilhøvet mellom arkitektonisk/teknisk utforminga av private heimar/sjukeheimar og pleietrengjande sin tilgang til WC. Bakgrunnen for 
denne avgrensinga er studiar som viser at bebuarar i norske sjukeheimar, aldersbustader og sjukehus kan mangle tilgang til funksjonelle baderom/toalett (Eek \& Lunde, 2014; Furu, 2008; Lunde, 2010). Ein analyse av tilkomst til og utforming av bad/WC i alle dei 20 kommunale sjukeheimane i Bergen kommune, viste at det sjeldan fanst stokk-/krykkehaldarar på bad/WC, sjølv om storparten av sjukeheimsbebuarane brukar stokk eller krykker (Boge, 2014, 2016; Boge, Callewaert \& Petersen, 2017; Boge \& Petersen, 2016). Baderomma var heller ikkje godt tilrettelagde for bebuarar som ikkje kunne stå på beina sine og som trong ulike former for heis i toalettsituasjonar, for ingen av dei 20 sjukeheimane hadde takheisskinner som var gjennomgåande mellom soverom og bad. Ofte var det heller ikkje mogeleg å justere handtaka eller høgda på WC. Toalett som kan justerast, gjere det mogeleg for bebuar å ha føtene på golvet og såleis sitje meir stabilt. Analysane viste vidare at bebuarane kunne ha problem med å nå toalettpapir og skyljemekanisme når dei sat på WC. Servanten kunne vere lite tilgjengeleg, det var ofte få st $\varnothing$ ttepunkt $i$ baderommet og det var vanlegvis ikkje mogeleg å sjå WC frå senga. Dei som har kognitiv svikt, slik 80 \% av norske sjukeheimsbebuarar har (Demensplan, 2015, s. 18), kan gløyme kvar WC er om dei ikkje ser det.

Det er ikkje berre i helseinstitusjonar tilgangen til WC kan vere utfordrande. Arkitekten Clara Greed (2004), som har studert offentlege toalett i engelske byar, argumenterer for, at i tillegg til at det er få WC i det offentlege rommet, er dei WC som finst ofte lite funksjonelle, spesielt for kvinner, då kvinner vanlegvis sit i slike høve. Den amerikanske arkitekten Alexander Kira (1976) argumenterte for at baderom er det viktigaste rommet i ei bygning, men også det som er dårlegast designa.

\section{Politisk strukturering av toalettpraktikkar}

Norske politikarar har vist stor interesse for toalettpraktikkar i private bustader og offentlege bygg. I siste halvdel av 1800-talet sette staten i verk eit storstilt arbeid for å få folk til å lette seg på utedo og kaggar. Dette var ein lekk i arbeidet med å gjere Noreg til eit moderne, demokratisk industrisamfunn. Men då Noregs fyrste sosiolog, Eilert Sundt, studerte urin- og avføringspraktikkar på Vestlandet på 1860-talet, oppdaga han at vanlege gardsbruk ofte mangla utedo. Folk flest føretrekte å lette seg ute i det fri, framfor på stinkande utedoar, men styresmaktene pressa på for å få folk til å slutte med slike friluftspraktikkar (Sundt, 1975/1869, s. 219-231).

I dag lettar ein seg vanlegvis på WC, men slike sanitære installasjonar er relativt nye oppfinningar. Dei fyrste WC med vasslås vart oppfunne i England og kom i alminneleg bruk der kring 1820 (Lundström, Hermansen \& Kellmer, 1978, s. 31). Noreg fekk sitt fyrste vassklosettet i 1850. WC var lenge eit statussymbol i det $\varnothing$ vre sosiale sjiktet.

Tilgang til vatn er ein føresetnad for WC. I 1950-1960 åra blei innlagt vatn med tilhøyrande avlaupsrøyr sentralt i den norske bustadpolitikken (Schiøtz, 2003, s. 410-413). På denne tida var den norske bustadpolitikken strengt regulert, fordi det var stor bustadmangel i Noreg i etterkrigstida (Kiøsterud, 2016). Etter kvart blei det utforma standardteikningar for husbankfinansierte bustader med bad og toalett. Seinare har bustadmarknaden i Noreg blitt liberalisert, men staten styrer framleis bustadbygginga ved hjelp av detaljerte forskrifter (Sintef, 2020). I fylgje slike forskrifter skal alle nybygde bustadhus ha bad og WC. I mange bustader er det krav om livslaupsstandard. Det vil seie at husværet skal vere utforma slik at ein kan bu der i alle livsfasar og ein skal sleppe å byte bustad om ein treng rullestol (Guldbrandsen \& Christophersen, 2011; Husbanken, 2020b).

Den norske staten strukturerer også toalettpraktikkane til dei som bur i sjukeheim. Dei siste 20 30 åra har det vore gjennomført eit monaleg arbeid for at norske sjukeheimar skal ha eit meir heimleg preg med kring 6-10 bebuarar i kvar avdeling (Regjeringen, 2013). I den samanheng har det vore lagt politiske føringar for at dei private einingane som inkluderer bad/WC, ikkje bør vere mindre enn 28 kvadratmeter. Bebuarrommet bør vere konstruert slik at det kan monterast pasientlyftar på traverskinne som kan forlengjast til toalettet/badet i bueininga. WC bør helst plasserast slik at bebuarane ser WC, fordi ei slik plassering hjelper bebuarar med kognitiv svikt å hugse kvar WC er 
plassert. Det er vidare føringar for at $\mathrm{WC} /$ baderom bør romme bruk av utstyr som rullator, rullestol, pasientlyftar, hygienestol og pleiepersonell. Badet bør minimum ha eit golvareal på $240 \times 240 \mathrm{~cm}$, det vil seie 5,88 kvadratmeter, men om badet skal romme st $\varnothing$ rre utstyr som fleksible dusj-stolar, bør det vere st $\varnothing$ rre (Arbeidstilsynet, 2020a; Husbanken, 2020a).

\section{Strukturering av bygg i private og offentlege soner som analytisk ramme}

Gjestar ville truleg blitt forundra om me skulle invitere til mat og prat på bad/WC eller i soverommet. Slike delar av eit moderne bygg vert gjerne rekna for private. I den private delen av bustaden vaskar og steller ein kroppar og her kvittar ein seg med kroppslege utsondringar. Når ein får gjestar oppheld ein seg gjerne i stovedelen av bustaden. Stova representerer på mange vis den offentlege delen av bustaden.

Pleiepersonell som hjelper pleietrengjande i toalettsituasjonar, arbeider vanlegvis i private delar av bygget, uavhengig av om den pleietrengjande bur heime, i ein sjukeheim, ein aldersbustad eller på eit sjukehus. Storparten av pleiarane er kvinner. Arbeidet deira med den biologiske kroppen ligg nedst i hierarkiet i det medisinske feltet (Norredam \& Album, 2007) og har låg status (Dahle, 2005; Isaksen, 1992; Lawler, 1996; Lee-Treweek, 1997; Stacey, 2005; Twigg, 2000).

Også i før-moderne samfunn vart kvinner sitt arbeid med den biologiske kroppen nedvurdert. Dette kjem tydeleg fram i Bourdieu (1996, s. 7-26) sine skildringar av det før-moderne kabylske huset. Dette huset var delt i to delar. Den største delen var lys og låg om lag ein halv meter høgre oppe enn den mørke, lågare delen. Den $\varnothing v r e$ delen var tiltenkt menneske, medan dyra heldt til i den lågare delen av huset. Denne mørke delen av huset romma også kroppsleg intimitet som kjønnsliv, barnefødslar og stell av døde. Den lågaste delen av huset vart rekna for å vere feminin, medan den $\emptyset v$ re delen vart rekna for å vere maskulin. Men også den $\emptyset v r e$ delen av huset hadde ein mørk del, og det var veggen ved sidan av inngangsdøra, like ved dyrestallen. Denne mørke veggen vart rekna for å vere feminin, og blei ofte kalla invalide-veggen, fordi sjuke og pleietrengjande blei plasserte ved denne veggen. Ein gjest som ein ville gjere ære på, blei ikkje plassert ved den mørke, feminine veggen.

Det er ein lang veg frå det pre-moderne kabylske huset til notidige private og offentlege bustader i Noreg, men i begge samfunn er det hovudsakleg kvinner som tek hand om pleietrengjande kroppar, med tilhøyrande handtering av kroppslege utsondringar. Slikt arbeid har låg status i begge kulturar. I 1996, då Bourdieu tok imot Goffman prisen, argumenterte han for at analysane av det kabylske huset og teorien om maskulin dominans framleis er relevant i vestlege sivilisasjonar (Bourdieu, 1996-1997).

Oppdelinga av det kabylske huset i reine og ureine delar har parallellar til antropologen Mary Douglas (1997/1966, s. 127-129, 130,143) sin teori om korleis reinsemd og ureinsemd skaper kategoriar og skilje i alle kulturar. Dette er ikkje ei naturleg inndeling, men resultatet av sosiale prosessar hevdar Douglas. Ho brukar blant anna det hinduistiske India som eksempel. Der reknar ein status ut frå reint og ureint: Dei lågaste kastane er dei ureine, og det er dei som arbeider med å fjerne kroppsleg avfall frå høgare kastar. Det er dei som vaskar tøy, klipper hår, steller lik og liknande. Dette hierarkiet kan forståast som eit kroppsleg bilete på samfunnet, der arbeidet er fordelt slik at hovudet tenkjer og ber, og dei mest forakta delane fjernar avfall. Dette er eit symbolsystem som har som hovudformål å halda orden på sosiale hierarki.

Konstruksjonar av reint og ureint i India og i det kabylske huset er på mange vis ei form for symbolsk vald (Bourdieu, 1996, s. 38-47). Strukturane avspeglar statusen til ulike sosiale agentar, samstundes som strukturane strukturerer måten agentane agerer på og reproduserer sosiale ulikskapar. Det som særpregar symbolsk vald er at ingen erkjenner at det finn stad ut $\varnothing v i n g$ av makt, verken den som utøver makt eller den som makta vert utøvd mot. Spelereglane er ikkje artikulerte og får individa til å akseptere den sosiale orden utan å opponere. Innafor gjeldande strukturar agerer agentar i pakt med den praktiske sansen som dei har inkorporert (Callewaert, 1997, s. 12-26). Det vil 
seie at dei gjer det som er praktisk mogeleg innafor gitte rammer. Dei objektive strukturane nedfeller seg i kroppen slik at den sosiale kjønnsdelinga, arbeidsmåtar og arbeidsdeling kontinuerleg vert vidareført og stadfesta.

I denne studien er tilgangen til WC analysert i lys av symbolske struktureringar av bygg i private og offentlege soner og i lys av den symbolske valden som kan vere innebygd i arkitektoniske og tekniske struktureringar (Bourdieu, 1996, s. 7-26; Bourdieu, 1996, s. 38-47; Bourdieu, 1998, s. 72-108). Analysane er basert på fylgjande spørsmål:

- Korleis strukturere arkitektur og teknologi tilgangen til WC?

- Korleis kan det vere at arkitektur og teknologi strukturer tilgangen til WC som det gjer?

Artikkelen er basert på analyser av intervju med pleiepersonell i heimesjukepleie, observasjon av toalettpraktikkar i sjukeheimar og på analyser av eigne erfaringar med tilgang til WC $\mathrm{i}$ tre tidstypiske norske private bustader og tre tidstypiske sjukeheimar. Dei eigne erfaringane som inneber ei historisering av tilgang til WC i Noreg, fungerer samstundes som ei objektivering av forskaren sin relasjon til forskingsaobjektet (Bourdieu, 2008; Callewaert, 2013, s. 110-118; Prieur, Kristiansen \& Jacobsen, 2002, omslag). Analysane er inspirerte av Birgitta Siegumfeldt's (1992) praxeologiske studie Renhed og Rammer om korleis idear om reint og ureint nedfelte seg i konstruksjon av skular $\mathrm{i}$ København på slutten av 1800-talet.

\section{Analyse del I: Tilgang til WC i private bustader}

Eg er fødd i 1957 og vaks opp på Nedre Boga på halvøya Bogøy ved Bjørnefjorden i Fusa kommune. I oppveksten hadde kommunen i underkant av 4000 innbyggjarar. Vel 200 av dei budde på Bogøy (Vangsnes, 2005, s. 351). Fram til slutten av 1800-talet/starten av 1900-talet, budde folk på Nedre Boga i eit felles tun. I slike tun levde menneske og dyr tett saman. Våningshusa var relativt små med få, små vindauge og låg takhøgd (Vangsnes, 2003, s. 360-385; 2005, s. 13-19).

\section{Tilgang til WC i private bustader på starten på 1900-talet}

I samband med jord-utskiftinga på slutten av 1800-talet/starten på 1900-talet, blei dette fellestunet oppløyst og folk bygde seg våningshus og løer i ulike delar av bygda. Familien min flytta til Klubbane på garden Nedre Boga. Garden grensa mot Bjørnefjorden. Her bygde oldefar, Mons Annanias Nilsson Boge (1861-1938) og Elna Marie Andersdotter Boge, fødd Hammarsland (1862-1927), ein sveitsarvilla i perioden 1900-1910. Denne byggjestilen var svært populær i Fusa-bygdene i perioden 1885-1920. Sveitsarhusa var større, lysare og luftigare enn husa i fellestuna hadde vore (Vangsnes, 2003, s. 360363).

Overgangen frå livet i relativt små hus med små vindauge der folk budde tett i fellestun til frittståande sveitsarvillaer på kvar sin gard, skulle bidra til effektivisering av jordbruket samstundes som frittståande sveitsarvillaer var ei realisering av moderne ideal om større avstand mellom folk, lys, luft og reinsemd. Moderne sjukepleie er på mange vis fundert i slike idear (Boge, 2008, s. 50-51; Nightingale, 1997/1860; Sydnes, 2001).

Som tidlegare nemnt, vart det sett i verk eit storstilt politisk arbeid i Noreg i siste halvdel av 1800talet for å få norske bygdefolk til å byggje og bruke utedo (Sundt, 1975/1869, s.219-231). Oldefar og oldemor ynskte nok å vere respektable, moderne borgarar. Dei hadde utedo med to seter $\mathrm{i}$ forlenginga av uthuset, om lag 10 meter frå bustaden, slik helseføresegnene på den tida kunne krevje i bygder ved Bjørnefjorden (Vangsnes, 2003, s. 384).

I sveitsarvillaen var det innlagt vatn, men ikkje WC, trass i at oldefar som dreiv tønnefabrikk (Vangsnes, 2003, s. 143-149), høgst sannsynleg hadde hatt økonomi til å legge inn WC. Men WC var 
uvanleg på Vestlandet på denne tida. I Bergen blei det fyrste WC installert i 1905. I 1918 var det berre 189 av bustadhusa i Bergen som hadde vassklosett (Lundström et al., 1978, s. 31; Økland, 2000, s. 15).

\section{Tilgang til WC i private bustader på 1950- og 1960-talet}

På Bogøy var det mange som installerte WC i våningshusa på midten av 1950-talet. Dette hadde truleg samband med at bygda fekk elektrisitet i 1952 (Vangsnes, 2005, s. 310-316). WC blei vanlegvis plassert på/i tilknyting til eit baderom med badekar. Til badekaret trongst varmt vatn og det kom frå ein elektrisk oppvarma tank. Mange av husa på Bogøy som var bygde før 1953 har eit påbygg med bad og WC.

I 1959 hadde 18\% av norske husvære bad (Dæhlie, 2006, s. 96-99). Om det var slik elles i landet som på Bogøy, at baderom og WC blei bygd samstundes, kan det sjå ut for at bygdefolk på Bogøy ikkje var spesielt seine med å installere WC i husa sine. Men det var ikkje alle i Fusa kommune som var glade for WC. Då ein familie i Sundfjord, ei bygd i den søre delen av Fusa kommune, bygde på bad og WC i 1972, reagerte den eldre generasjonen negativt. Dei meinte det var galskap å plassere skithuset inne i bustaden (Vangsnes, 2003, s. 385). WC inne i våningshuset braut truleg med dei eldre sine førestillingar om korleis ein strukturerer reint og urein (Douglas, 1997/1966) og WC i våningen braut med den praktiske sansen (Callewaert, 1997, s. 13-26) som dei hadde inkorporert gjennom eit langt liv med utedo.

Farfar, Nils Boge (1899-1982) og farmor Karoline (Lina) Boge, fødd Tveit (1901-1971), var nok relativt moderne. Dei overtok sveitsarhuset etter oldefar og installerte bad og WC i eit av romma i andre etasje i på 1950-talet. Når eg brukte deira WC i andre etasje var eg åleine. Det var eg vanlegvis ikkje når eg besøkte onkelen min og hans familie som budde i fyrste etasje. Dei brukte utedoen inntil dei fekk laga påbygg med bad og WC. På utedoen som hadde to seter, sat eg ofte saman med eit søskenbarn. Av og til blei me sitjande lenge og småprata. Innimellom bladde me gjerne i vekeblad. WC og utedo med to seter strukturerte med andre ord toalettpraktikkane på ulike vis.

Foreldra mine, Roald Boge (1932-2016) og Marie Boge, fødd Ekornåsvåg (1929- ) bygde seg hus på garden til farmor og farfar på Nedre Boga. I 1960 flytta me inn i nytt husbankfinansiert Rødlands-hus på om lag 80-85 kvadratmeter. I 1960 hadde norske husbankfinansierte einebustader ein gjennomsnittleg storleik på 83,6 kvadratmeter (Husbanken, 1961, s. 11). Huset hadde stove, kjøkken, tre soverom, bad og WC. Badet var på om lag 2,5 kvadratmeter. Det var dør frå foreldresoverommet og d $\varnothing \mathrm{r}$ frå WC til badet. WC-rommet som me måtte passere for å kome til badet, var om lag ein kvadratmeter. Alle rom i bustaden var på eit plan, men det var høge dørtersklar mellom WC og gang og mellom WC og bad, så det var ikkje mogeleg å ta seg inn på bad/WC med rullestol. Huset var eit ektefødd resultat av den norske bustadpolitikken som rådde i Noreg i etterkrigstida (Kiøsterud, 2016).

\section{Tilgang til WC i private bustader på 2019-2020}

I husværet som mannen min og eg kjøpte i 2020 er det to bad/WC. Det eine badet har berre inngang frå det største soverommet. Bustaden har heis og såkalla livsløpsstandard (Husbanken, 2020b), men det er tydeleg at arkitekt og utbyggjar ikkje har hatt ustødige pleietrengjande i tankane ved plassering av sanitært utstyr på bad/WC, trass i at bustadkomplekset elles er skreddarsydd for dei som vil leve resten av livet i eit husvære med alle rom på eit plan og lett tilgang til parkering, butikk, apotek, fris $\varnothing$, restaurant og offentleg transport.

For å få meir kunnskap om pleietrengjande sin tilgang til WC i private bustader, gjorde eg intervju (Hansen, 2009, s. 62-77; Ågotnes, Lea \& Petersen, 2019) i 2019 med pleiepersonell i ein relativt stor kommune på Vestlandet om deira erfaringar med toalettpraktikkar i heimesjukepleia (2018/2119/REK Vest /NSD 647263). Studien er sett på vent på grunn av koronapandemien, så eg har 
diverre ikkje fått intervjua pleietrengjande, men før pandemien braut laus, intervjua eg to helsefagarbeidarar og ein sjukepleiar. Kommunen har fleire heimesjukepleiedistrikt.

Helsefagarbeidarane arbeidde i eit heimesjukepleiedistrikt medan sjukepleiaren arbeidde i eit anna heimesjukepleiedistrikt. Dei to heimesjukepleiedistrikta omfatta kyst-bygder som likna mykje på bygda eg sjølv vaks opp i. Folk flest bur i einebustader. Enkelte bur i omsorgsbustader eller sjukeheimar. Dei tre som eg intervjua hadde meir enn ti års erfaring frå heimesjukepleie i den aktuelle kommunen. Dei hadde vaske opp på landsbygda i familiar som har drive små familieverksemder eller dei hadde kombinert små gardsbruk med attåtnæringar. Slike kombinasjonar har vore vanlege på landsbygda på Vestlandet (Vangsnes, 2003, s. 52-53)

\section{Motstand mot å flytte private, intime gjeremål til offentlege delar av bustaden}

Pleiarane fortalde at rommet som WC er plassert i (den private delen av bustaden) er ofte så trongt at pleietrengjande ikkje kjem seg inn med rullator:

Ja, for det er jo veldig trongt då. Dei kjem ikkje inn med rullator. Det er ofte det som er grunnen til at dei får toalettstol. Det er vanskeleg å forflytte seg med rullator til do i gamle hus ... trongt ... dei må ta seg for med hendene og då vert dei endå reddare (Helsefagarbeidar 2).

På grunn av kronglete små bad, høgde dørtersklar og trapper må pleietrengjande flytte senga til bestestova (den offentlege delen av bustaden) og ha toalettstol der:

Nesten alle gamle hus er vanskelege. Kronglete, små bad og WC med høge dørtersklar. Ofte søv dei oppe på loftet og så skal dei ned trappa på do, så då må dei flytta i stova.... Ho har to stover. Bestestova har ho gjort om til soverom. Der har ho seng og toalettstol.... Det er altfor langt bort til do frå bestestova... Baderommet er plassert ein annan stad langt inne i den lange gangen.... (Sjukepleiar).

Pleietrengjande som har toalettstol og seng i stova kan tykkje at det er flaut og dekker gjerne toalettstolen til når dei ventar gjestar:

Når ho ventar besøk vil ho at eg skal dekke den (toalettstolen) til med eit teppe. ... Flaut. Det er ikkje lett (Helsefagarbeidar 2).

Det kan vere stor motstand mot å sove og å gjere frå seg på toalettstolar i stover. Slike praktikkar kan bryte med inkorporerte normer for reint og ureint (Pierre Bourdieu, 1996; Douglas, 1997/1966; Callewaert, 1997). Ei av pleiarane hadde kjempa for å få mora til å bruke toalettstol i stova. Mora klarte ikkje å gå opp og ned trappene til soverommet i andre etasje i det gamle huset. Mora klarte heller ikkje å gå til WC som var på same plan som stova, men ho var i stand til å bruke ein toalettstol om den stod ved senga i stova:

Eg hadde jo ei mor som måtte ligge i stova. Ho klarte ikkje å gå til toalettet. Det var ein stor kamp for å få henne til å bruke toalettstol i stova.... (Helsefagarbeidar 1).

Dei som har toalettstol i stova kan vere redde for søl og lukt, så enkelte dekker til tepper og golv med papirkladdar som dei lett kan snuble i og som kan gjere det vanskeleg å ta seg fram med rullator:

... ho har jo berre eit svært trongt toalett.... Toalettstolen står $i$ stova ved senga. Ho har seng i stova...Og så er det jo slik at for å beskytta tepper og golv har dei lagt fullt med kladdar rundt omkring.... Det er lett å snuble i kladdane og dei gjer det vanskeleg å kome seg fram med rullator. Det hadde vore enklare å ta vekk tepper og kladdar, men det er ikkje alltid så 
enkelt å få gjere om på ting og tang i heimane til folk. Dei må få lov å ha da slik som dei likar best (Helsefagarbeidar 1).

Pleiarane har erfart at det ikkje berre er motstand mot toalettstolar og senger i stover, men ein generell motstand mot ommøblering. Pleietrengjande og deira pårørande vil helst at huset skal sjå ut slik dei var vande med å ha det:

Det er eit av dei største problema i heimesjukepleia, dei vil veldig lite forandra i heimen. Dei vil ha det slik som det har vore. Dei vil for eksempel helst ikkje ha inn ein toalettstol i stova. Det er utruleg vanskeleg. Det er veldig mange prosessar for å få det til.... Det er veldig trongt. Det er ikkje tilrettelagt.... Det vert jo ein omfattande prosess, men dei kunne ha flytta ut spisebordet og hatt ei seng i stova og ein toalettstol og ein manuell heis, så hadde det vore noko heilt anna. Dei vil helst ikkje røra noko. Spisebordet skal stå der det har stått og sofaen skal stå der den har stått. Eg blei kritisert fordi eg drog fram kvilestolen og fekk ein barsk beskjed frå pårørande om å sette den inntil veggen att. Når stolen står i veggen kan ikkje brukar regulere den bakover og kvile. Ommøblering er eit av dei største problema. Det er ikkje kjekt (Helsefagarbeidar 1).

$\AA ̊$ byte ut ordinære låge senger med regulerbare sjukesenger kan innebere at den pleietrengjande og partnaren deira må sove i kvar si seng og gjerne i kvar sitt rom. Det kan vere sårt:

Dei sto lenge på sitt, at dei ikkje skulle ha sjukeseng fordi dei ville sove i same seng. Han måtte flytte ut (frå soverommet) for å få plass til sjukeseng. Det var kjempetrist.... Det var ikkje plass i rommet til to sjukesenger ved sidan av kvarandre (Sjukepleiar).

Sjølv om spesielt eldre hus kan by på utfordringar når pleietrengjande skal lette seg for urin og avføring, er toalettpraktikkar heller ikkje uproblematisk i nyare husvære på grunn av tersklar og nivåforskjellar:

Han ligg i sjukeseng i den einaste stova dei har og så har han toalettstol og ein god stol ved sida av. Han bur i et relativt nytt hus og har soverom i same etasje og bad og toalett rett innafor soverommet, men det er ein kjempestor terskel for å koma inn på soverommet, for stor til å laga terskelforhøyar. Soverom, bad og toalett er eit trappetrinn opp. Kona søv på soverommet (Sjukepleiar).

\section{Gamal vane er vond å venda}

Sjølv om ein bur i relativt godt tilrettelagde einebustader med bad/WC ved sidan av soverommet, kan det vere problem for ust $\varnothing$ dige og kraftlause pleietrengjande å bruke WC sjølv om dei har preikestol. I slike høve kunne det vere mogeleg å transportere pleietrengjande ved hjelp av ein heis, men pleietrengjande kan nekte å bruke heis:

Ho bur i eit moderne og godt tilrettelagt hus med baderom rett innanfor soverommet. Ho går fram og attende mellom stolen og toalettet. Men ho klarer ikkje å reise seg sjølv. Ho har ein elektrisk stol som me tippar veldig høgt opp. Toalettet er lågt, så det vert slitsamt å fylgje henne på toalettet, sjølv om ho har eit moderne og godt utstyrt bad med forhøyar og handtak ved toalettet. Der må me vera to og dra og skubba for å få henne opp. Ho har to handtak relativt høgt oppe på veggen som ho brukar til å dra seg opp med, men ho har svært lite krefter. Ho er stor og tung og klarer ikkje å koma seg opp på eiga hand... Ho klarer å gå i preikestol med folk rundt seg, men det er ingen som vil gå med henne åleine for det er litt for risikabelt. Og brukaren blir heilt hysterisk når me prøver å bruke heis ... (Sjukepleiar). 
At pleietrengjande vegrar seg mot å bli heist frå seng til WC kan ha samband med at dei ikkje er vande med å ta seg til WC på den måten. Dei har inkorporert at ein går til WC. Inkorporerte praktikkar kan også bidra til å forklare at pleietrengjande som flyttar til nye bustader med enkel tilgang til WC på romslege bad, ikkje brukar WC sjølv om dei er i stand til det, fordi dei har vore vande med å bruke toalettstol:

Ho har flytta i omsorgsbustad og har stort fint bad rett ved sida av soverommet, men ho brukar toalettstolen dag og natt fordi det var slik ho hadde det heime.... ho hadde brukt toalettstol i mange år då ho flytta til omsorgsbustad. Ho går med rullator og kunne utan problem kome seg til toalettet $i$ omsorgsbustaden når ho vil, men vel altså å bruke toalettstolen. Ho tømer toalettstolen sjølv (Sjukepleiar).

\section{Oppsummering og objektivering, analyse del I}

Analyse del I viser at sveitsarvillaen som stod ferdig i 1910, Rødlands-huset frå 1960 og bustaden frå 2020 strukturerer toalettpraktikkar på ulike vis.

Sveitsarvillaen frå 1910 var strukturert slik at ureinskapar i form av urin og avføring blei avlevert på ein utedo som var plassert om lag 10 meter unna våningshuset.

I det husbankfinansierte Rødlands-huset frå 1960 vart urin og avføring avlevert på WC i eit eige rom inne i huset. Bad/WC var plassert mellom to soverom.

I bustaden frå 2020 er det eit lite gjeste-bad/WC i gangen. I tillegg er det eit større bad med WC som kun har inngang frå det største soverommet.

Det er relativt stor forskjell på struktureringa av private og offentlege delar av våningen i dei tre tidstypiske bygga. I sveitsarvillaen trong ein ikkje vere åleine i toalettsituasjonar og det var ikkje koplingane mellom soverom og bad/WC som i Rødland-huset frå 1960. Der var det dør frå det såkalla foreldresoverommet til badet, men ein kunne også kome inn på det same badet via WC. I husværet frå 2020 er det ei endå tydelegare privatisering av foreldresoverommet og bad/WC, ved at det eine badet er bygd slik at ein må gå inn på dette soverommet for å kome til det største badet med WC.

I bygget frå 2020 er det lagt betre til rette for at pleietrengjande kan bruke toalettfasilitetane enn i sveitsarvillaen frå 1910 og det husbankfinansierte huset frå 1960-talet, men heller ikkje bygget frå 2020 er optimalt. Dersom ein hadde hatt ust $\varnothing$ dige eldre i tankane ved utforminga av bad/WC, ville dei sanitære installasjonane vore plasserte slik at ein lett kunne ta seg over til servanten $\mathrm{i}$ toalettsituasjonar og det ville ha vore lagt til rette for montering av traverskinner til takheis.

Når bygg er konstruerte slik at pleietrengjande ikkje har tilgang til WC, kan det vere nødvendig å legge om toalettpraktikkar. Dette kan det vere motstand mot. Spesielt stor motstand kan oppstå når ein må flytte senga til stova og må gjere frå seg på ein toalettstol der. Motstanden kan ha samband med at slike endringar inneber ei omstrukturering av private og offentlege soner i bustaden som kan bryte med pleietrengjande og deira pårørande sin inkorporerte bruk av bustaden (Bourdieu, 1996, s. 7-26). Det at ein kan halde fram med å bruke dostol sjølv om ein får lett tilgang til WC, viser korleis ein inkorporert praktisk sans kan forme toalett-praktikkar (Callewaert, 1997, s. 13-26).

\section{Analyse del II: Tilgang til WC i norske sjukeheimar}

Denne delen av artikkelen er basert på analyser av tilhøvet mellom arkitektur/teknikk i norske sjukeheimar og toalettpraktikkane til pleietrengjande som ikkje kan stå/gå.

Noreg har hatt pleieinstitusjonar sidan midten av 1800 -talet. I etterkrigstida har det vore politisk interessant å halde eldre borte frå kostbare akutt-sjukehus-senger, dersom dei kan få den hjelpa dei treng i sjukeheimar (Martinsen, 2003, s. 208-214). I etterkrigstida blei namnet endra frå 
pleieinstitusjon til sjukeheim fordi spesielt legane meinte det passive namnet pleieheim måtte erstattast med det aktive namnet sjukeheim, som kunne gje assosiasjonar til aktiv behandling (Hauge, 2004, s. 13-20).

\section{Tilgang til WC i sjukeheim frå 1960-talet}

Den fyrste sjukeheimen i Fusa kommune blei opna i 1963. Dette var ein blanding av alders- og sjukeheim. I perioden 1972-1977 hadde eg sommarjobbar ved denne institusjonen. På den tida budde det, så vidt eg kan hugse, fire eller fem bebuarar der som ikkje kunne stå/gå i institusjonen. Bygget var frå 1899 og det var opphavleg eit hotell. Seinare har det vore brukt som feriekoloni, som heim for jenter med tuberkulose, som heim for psykisk utviklingshemma og som sjuke- og aldersheim (Vangsnes, 2005, s. 158-162). Institusjonen hadde tre etasjar, men var utan heis. Dei friskaste budde i andre etasje. Dei mest pleietrengjande budde i fyrste etasje. Nokre budde i dobbeltrom. Dei fleste hadde eige rom. Det var ikkje bad/WC i tilknyting til soveromma, men det var nokre små WC i gangområdet. I tillegg var det eit relativt stort bad/WC med badekar. Så vidt eg kan hugse, kunne over halvparten av bebuarane vaske og stelle seg sjølve og dei fleste kunne gå på WC utan hjelp. Dei som ikkje kunne gå/stå, brukte bekken i seng. Eg kan ikkje hugse at det var tekniske pasientlyftarar i sjukeheimen.

Etableringa av sjukeheimen i Fusa i 1963 hadde truleg samband med at det skulle vedtakast ei lov i 1964 om at det offentlege hadde hovudansvaret for pleie og omsorg. På midten av 1960-talet budde om lag 25000 i pleieinstitusjonar for eldre og funksjonshemma i Noreg. Parallelt med etableringa av pleieinstitusjonar starta ei gradvis utbygging av heimebaserte pleie- og omsorgstenester (Borgan, 2010, s. 7-8).

\section{Tilgang til WC i sjukeheim frå 1970-talet}

På 1970-talet blei det bygd mange sjukeheimar i Noreg. Ofte i form av sjukehusliknande avdelingar med opp til 30 bebuarar i ein lang gang (Hauge, 2004, s. 13-20). I 2004 og 2006 gjorde eg studiar om kroppsleg pleie i ein sjukeheim som var bygd på 1970-talet (Boge, 2008, s. 82). Dei som budde i denne institusjonen var mykje meir pleietrengjande enn dei som budde i sjukeheimen i Fusa på 1970talet. Denne endringa kan ha samband med at terskelen for å få plass i sjukeheim er blitt relativt høg etter ei massiv utbygging av heimesjukepleie. Slike heime-tenester blei lovpålagt i Noreg i 1982 (Holvik, 2018s. 24-35). Sjukeheimen som var bygd på 1970-talet var mykje meir moderne og likna meir på eit sjukehus enn det sjukeheimen i Fusa frå 1963 hadde gjort. I 1970-tals sjukeheimen budde det 27-28 pleietrengjande i kvar avdeling. Om lag 2/3 budde på tomanns rom og delte bad/WC med tre andre bebuarar, medan om lag $1 / 3$ budde på enkeltrom med eige bad/WC. I tillegg var det enkelte felles WC i tronge rom i gang-soner (Boge, 2008, s. 82).

Dei pleietrengjande som deltok i studien trong hjelp til kroppsleg pleie. Ei av dei var ei kvinne med eige rom og bad/WC. Ho kunne ikkje kunne stå/gå. Pleiarane brukte ein frittståande pasientlyftar når dei skulle hjelpe henne til og frå toalettet. Det gjorde dei vanlegvis $f ø r$ dei plasserte henne i ein rullestol om morgonen. Når kvinna sat oppe i rullestolen hadde ho på seg ei stor bleie som absorberte mykje urin. Ho kunne bli sittande heile dagen i den våte bleia. Kvinna lurte på om det var derfor ho ofte klødde nedantil: «.... av og til så tenkjer eg at det må vera noko som gjer at eg klør bakendes». Pleiepersonell stadfesta at pleietrengjande som er avhengige av heis for å koma seg på WC kan bli sitjande i våte bleier, men skulle det koma avføring, heiste dei bebuarane opp att i senga for å skifte. I slike høve blei dei som budde i denne 1970-talls sjukeheimen gjerne verande i senga til neste morgon. Det blei for arbeidskrevjande å hente den frittståande heisen og heise bebuarane opp i senga, skifte på dei, ta dei opp att i rullestol og køyre dei inn att i stova, for så å heise dei i seng att om kvelden (Boge, 2008, s. 128). 


\section{Tilgang til WC i sjukeheim frå 2000-talet}

I 2013 gjorde eg observasjonar av toalettpraktikkar i to sjukeheimar som var bygde/rehabiliterte i 2003 og 2004. Kriteriet for å delta i studien var at ein trong hjelp frå pleiepersonell i toalettsituasjonar. 16 bebuarar (12 kvinner og fire menn) blei inkluderte (2012/1854/REK vest). Alle hadde eigne bueiningar på om lag 20-25 kvadratmeter, inkludert eige bad/WC på om lag 4-5 kvadratmeter. Einingane var utforma i samsvar med statlege føringar for slike bygg (Arbeidstilsynet, 2020b; Boge et al., 2017; Husbanken, 2009; Regjeringen, 2013, s. 99-108). Fire av dei 16 bebuarane som blei observert i 2013 brukte sjeldan og aldri WC eller toalettstol. Dette var fire kvinner som alle var lamma/hadde paresar på halve sida av kroppen. Den andre halvdelen av kroppen var også kraftlaus då me møttest, kanskje fordi dei var gamle (80-89 år) og kanskje fordi den friskaste delen av kroppen hadde vore lite i bruk etter at hjerneskaden oppstod. Ei av dei fire kvinnene kunne snakke. Ho hadde kognitiv svikt. Det var uklart korleis den kognitive funksjonen til dei tre andre som ikkje kunne stå/gå var, for dei kunne ikkje uttrykke seg verbalt eller skrifteleg. Desse fire kvinnene som ikkje kunne stå eller gå, avleverte all urin og avføring i bleier. Det var uklart om dei kjende trong for å lette seg for urin og avføring, eller om dei berre kjende når det allereie hadde kome noko i bleia. Dei var ikkje i stand til å gjere adekvat bruk av veggfast eller arm-fast alarm, og gav heller ikkje tydelege nonverbale signal om når dei hadde trong for å lette seg. Men tre av dei gav tydeleg uttrykk for at dei mislikte å bruke bleier. Dersom det var mogeleg reiv dei bleia vekk med den handa som hadde litt kraft. Dette skjedde spesielt om natta når dei hadde mindre klede på seg.

\section{Heis som er festa på takheisskinner ved seng}

Desse fire kvinnene som ikkje kunne stå på føtene måtte heisast i seng og skifte bleie om det kom avføring. I sjukeheimane som var bygde i 2003 og 2004 var det takmontert heis mellom seng og stol/rullestol. Desse takmonterte heisane i seng-området kan vere bakgrunnen for at bebuarane i desse nokså nye sjukeheimane relativt enkelt kunne bli heiste opp att i rullestolen og transportert til fellesareala etter at skiftinga var unnagjort. I 1970-tals sjukeheimen var det ikkje takmonterte heisskinner, og der blei bebuarane liggjande resten av dagen om dei trong skifting imellom morgonog kveldsstellet (Boge, 2008, s. 128).

\section{Ingen takheisskinner mellom seng og bad/WC}

Trass i takheis mellom seng og rullestol og relativt moderne bad på fire - fem kvadratmeter, brukte dei fire bebuarane som ikkje kunne stå på føtene aldri WC i sjukeheimane som var bygde/renoverte i 2003 og 2004.

Fråveret av takmonterte heisar mellom seng og bad/WC kan vere grunnen til at dei ikkje brukte WC, for dei pleietrengjande kunne ikkje transporterast med takmontert heis frå seng til WC og attende. Det var ikkje mogeleg å montere takheisskinner, fordi det var ulik takhøgd i soverom og bad. Slike nivåforskjellar er det i alle dei 20 offentlege sjukeheimane i Bergen kommune (Boge, 2014, s. 94).

\section{WC og toalettstolar som ikkje er tilpassa ustødige kroppar}

Om det hadde vore gjennomgåande takheisskinner mellom seng og bad/WC er det ikkje sikkert at bebuarar som var ustødige og ikkje kunne stå/gå hadde, brukt WC likevel, for dei kan ha problem med å sitte st $\varnothing$ dig på eit vanleg WC eller ein enkel toalettstol. Slike bebuarar kan trenge spesiallaga WC/toalettstolar, men slike innrettingar var ikkje tilgjengelege. Eg observerte heller ikkje bruk av spesialbygde WC/toalettstolar i 2008-2011, då eg rettleidde bachelor-studentar i sjukepleie som hadde praksis i ulike norske sjukeheimar. 
Observasjonane er i pakt med studiar som viser at sjukeheimar kan mangle design og utstyr som er tilpassa dei pleietrengjande (Boge, 2014; Boge et al., 2017; Furu, 2008; Lunde, 2010; Nettleton, Buse \& Martin, 2018).

\section{Bleier i staden for toalettstol på grunn av lite personale}

Ei av kvinnene som ikkje kunne stå/gå, kunne sitte stødig i ein enkel toalettstol. Det hadde ho tidlegare gjort kvar morgon og kveld. Då hadde ho avlevert både urin og avføring. På det viset vart det mindre innhald i bleiene. Då eg gjorde feltarbeid i 2013 var desse toalettpraktikkane avslutta fordi pleiarane ikkje hadde tid til å vere i rommet når ho sat på toalettstolen. Kvinna avleverte all urin og avføring i ei bleie med stor absorpsjonsevne som vanlegvis blei skifta morgon og kveld. Dette viser at bemanning av sjukeheimar også er vesentleg for at pleietrengjande skal få den hjelp dei treng $\mathrm{i}$ toalettsituasjonar, men slike tilhøve er ikkje analysert i denne artikkelen.

\section{Oppsummering og objektivering av analyse del II}

I analyse del I og II har me sett at arkitektur og teknologi strukturer tilgangen til WC på ulike vis. I hotellet frå 1899 som var bygd om til sjukeheim i 1963, var det WC ute i gangen i rom som var mindre enn ein kvadratmeter. Desse WC blei ikkje brukt av bebuar som ikkje kunne stå/gå, både fordi dei var for små til å romme både pleietrengjande og pleiar og fordi sjukeheimen ikkje hadde pasientlyftar som kunne transportere pleietrengjande til WC eller toalettstol. Bebuarane kunne bruke bekken når dei låg til sengs.

I sjukeheimen som var bygd på1970-talet var det nokre bebuarar som hadde einerom med tilhøyrande bad/WC. I denne sjukeheimen var WC plassert i eit større rom enn tilfellet var i sjukeheimen frå 1963, men både badet og soverommet i bueininga til dei som hadde einerom med eige bad/WC i 1970-tals bygget var relativt små. Eg gjorde inga oppmåling av bad/WC, men i ein sjukeheim som var bygd i Bergen i 1972 var bad/WC om lag tre kvadratmeter (Boge, 2014, s. 85). Det er rimeleg å anta at badet til den ovanfor nemnde kvinna ikkje var større enn tre kvadratmeter. Det var berre så vidt det var plass til ein transportabel pasientlyftar på soverom og bad. Slik arkitektur kan ha bidratt til at pleietrengjande som ikkje kunne stå/gå, blei sitjande i våte bleier store delar av dagen. Om pleietrengjande på dagtid måtte skifte bleie på grunn av avføring, blei dei liggjande til sengs til neste morgon. Det blei for tungvint og tidkrevjande å heise dei til og frå rullestol/seng oftare.

I sjukeheimane som var bygde/rehabiliterte i 2003-2004, var bueiningane om lag dobbelt så store som eineromma med bad var i bygget frå 1970-talet. Heller ikkje desse romslege einingane hadde ein arkitektur og teknologi som var tilpassa bebuarar som ikkje kunne stå/gå. Dei fekk ikkje bruke WC. Urin og avføring blei avlevert i bleier.

Når sjukeheimar er konstruerte slik at pleietrengjande ikkje har tilgang til WC eller toalettstol, må dei avlevere all urin og avføring i bleier. Sjølv om pleietrengjande ikkje snakkar, kan dei gje tydeleg uttrykk for at dei ikkje likar bleier, og dei kan prøve å fjerne bleia når dei får tak i den, om dei har kraft i den eine handa. Motstanden mot bleier kan ha samband med at det er ubehageleg å lette seg $\mathrm{i}$ bleier og med at bleiebruken bryt med den praktiske sansen deira (Callewaert, 1997, s. 13-26). Dei har vore vande med å lette seg på WC i private delar av bustaden (Bourdieu, 1996, s. 13-26).

\section{Homologe struktureringar av tilgang til WC i sjukeheimar og private bustader}

Tilgangen til WC i sjukeheimane som var bygde/ombygde i 1963 og 1970 er på mange vis homolog til bad/WC utforminga i den husbankfinansierte bustaden frå 1960. At dei er homologe tyder ikkje at romma er heilt like, men at dei ser ut for å vere funderte i dei same ideane om korleis ein utformar 
bad/WC (Halskov, Lundin \& Petersen, 2008). Både i den private bustaden og i dei nemnde sjukeheimane er bad og WC relativt små og lite tilgjengelege for dei pleietrengjande.

Bad/WC-utforminga i sjukeheimane frå 2003 og 2004 er på mange vis homolog til utforminga av bad/WC i privatbustaden med livslaupsstandard frå 2020. Nyare private bustader og sjukeheimar er betre tilrettelagde for ust $\varnothing$ dige og kraftlause pleietrengjande enn eldre bygg, men heller ikkje i dei nyaste private bustadane og sjukeheimane er det lagt til rette for at pleietrengjande som ikkje kan stå på føtene, skal kunne bruke WC.

Både i sjukeheimar og private bustader, er det relativt stor forskjell på strukturering av private og offentlege soner i nye og gamle bygg. I sveitsarvillaen frå 1910 var det inga kopling mellom soverom og toalett. Det var det heller ikkje i sjukeheimen frå 1963 som opphavleg var bygd som hotell i 1899. I husbankhuset frå 1960 og sjukeheimen frå 1970-talet er det ei mykje tydelegare kopling mellom soverom og bad/WC enn i dei eldre bygga. I sjukeheimane frå 2003 og 2004 og i bustaden med livslaupsstandard frå 2020 er det ei endå tydelegare privatisering av soverom/bad/WC-delen av bygget enn i dei eldre bustadene.

\section{Homologe struktureringar av private og offentlige soner i før-moderne og notidige bustader/bueiningar}

Teori om strukturering av bygg i offentlege og private soner kan bidra til å forklare at arkitektur og teknologi strukturer toalettpraktikkar som det gjer i private bustader og sjukeheimar. Om ein ser på den norske private notids-bustaden og notids-bueininga i sjukeheimar i lys av det før-moderne kabylske huset som var delt i ein øvre og ein nedre del (Bourdieu, 1996, s. 7 - 26), er bad/WC og soverom i notidsbustaden og bueininga i sjukeheimen på mange vis homolog til den feminine, lågaste delen av det kabylske huset, fordi det er i slike delar av bustaden ein handterer den biologiske kroppen.

\section{Symbols vald}

Gjeremåla som fann stad i den lågaste delen av det kabylske huset vart rekna for feminine og dei hadde låg status (Bourdieu, 1996, s. 7-26). Den same låge statusen har arbeidet med toalettpraktikkar i helsevesenet (Dahle, 2005; Isaksen, 1992; Lawler, 1996; Lee-Treweek, 1997; Stacey, 2005; Twigg, 2000). Slikt arbeider er sjeldan artikulert og problematisert i det offentlege rommet. Lite artikulering kan bidra til å forklare at private bustader og sjukeheimar er utforma slik at ein del pleietrengjande ikkje har tilgang til WC. For når praktikkane er tause, vil ikkje arkitektar og ingeniørar få informasjon om korleis arkitektur og teknologi kan fremme/hemme toalettpraktikkane til dei sjukaste og mest pleietrengjande. Difor er det sannsynleg at dei vil halde fram med å konstruere private og offentlege bygg som er i pakt med den praktiske byggsansen som dei har inkorporert (Callewaert, 1997, s. 13-26). Når arkitektar og ingeniørar konstruerer bygg som hindrar dei mest pleietrengjande i å bruke WC, utøver dei samstundes symbolsk vald (Bourdieu, 1996, s. 3847). 


\section{Referansar}

Arbeidstilsynet. (2020a). Arbeidsmiljø i helseinstitusjonar. I. Henta frå https://www.arbeidstilsynet.no/tema/utforming-av-arbeidsplassen/arbeidsmiljo-ihelseinstitusjoner/

Arbeidstilsynet. (2020b). Krav til fysisk arbeidsmiljø i omsorgsboliger og sykehjem. I: Arbeidstilsynet. Henta frå https://www.arbeidstilsynet.no/tema/byggesak/veiledning-til-dokumentasjonskravved-soknad-om-arbeidstilsynets-samtykke/krav-til-fysisk-arbeidsmiljo/

Boge, J. (2008). Kroppsvask i sjukepleia Universitetet i Bergen, Bergen. Henta frå http://hdl.handle.net/11250/2579522

Boge, J. (2014). Funksjonaliteten til baderom i sjukeheim. Senter for omsorgsforskning Vest Henta frå https://brage.bibsys.no/xmlui/bitstream/handle/11250/278230/1/Rapport11_14_web.pdf

Boge, J. (2016). Ufunksjonelle baderom i sjukeheimar. ArkitekturN, 5, 80-83. Henta frå http://www.fagpressenytt.no/artikkel/ufunksjonelle-baderom-i-sjukeheimar

Boge, J. (2020). Kroppsleg hygiene. Omsorgsbiblioteket https://omsorqsforskninq.braqe.unit.no/omsorqsforskning-xmlui/handle/11250/2656145

Boge, J. (2021) A praxeological apporach to constructions of social science. Norsk oversetting: Ei praxeologisk tilnærming til konstruksjonar av samfunnsvitskapleg viten. Praxeologi - et kritisk refleksivt blikk på sosiale praktikker, volum 3. https://boap.uib.no/index.php/praxeologi/article/view/3161/3199

Boge, J., Callewaert, S. \& Petersen, K. (2017). The Impact of Bathroom Design on Privacy for Users with Special Needs. Ageing International, 27, 21-18. https://doi.org/10.1007/s12126-1201719311-12129.

Boge, J. \& Petersen, K. (2016). Dei som ikkje får kome på toalettet. Bergens Tidende, 25.10. Henta frå http://www.bt.no/btmeninger/debatt/Dei-som-ikkje-far-kome-pa-toalettet-325169b.html

Borgan, J.-K. (2010). Pleie- og omsorgsstatistikk 1962 - 2010. Olso - Kongsvinger: Statistisk Sentralbyrå. Henta frå https://www.ssb.no/a/publikasjoner/pdf/rapp_201210/rapp_201210.pdf

Bourdieu, P. (1996). Symbolsk makt: artikler i utvalg. Oslo: Pax.

Bourdieu, P. (1996 -1997). The Goffman Prize Lecture: Masculine Domination Revisited. Berkely Journal of Sociology, 41, 189-203. https://doi.org/https://www.jstor.org/stable/41035524?seq=1

Bourdieu, P. (1998). Tre former for teoretisk viden. I K. Petersen \& S. Callewaert (Red.), Pierre Bourdieu. Centrale tekster inden for sociologi og kulturteori. København: Akademisk forlag.

Bourdieu, P. (2008). Utkast til en selvanalyse. Oslo: Pax Forlag.

Callewaert, S. (1997). Om den praktiske sans som noget kropsligt. I P. o. R. Institutt for Filosofi (Red.), Bourdieu-studier I. København: Københavs Universitet Amager.

Callewaert, S. (2013). Pierre Bourdieu. I H. Andersen \& L. Kaspersen (Red.), Klassisk og moderne samfunnsteori. København: Hans Reitzels Forlag.

Dahle, R. (2005). Kropp og aldring i moderne samfunn IR. Nord, G. Eilertsen \& T. Bjerkrem (Red.), Eldre i en brytningstid. Oslo: Gyldendal Akademisk.

Darbyshire, P., Ralph, N. \& Caudle, H. (2015). Editorial: Nursing's mandate to redefine the sentinel event. Journal of Clinical Nursing https://www.researchgate.net/publication/280536377_Editorial_Follow_the_yellow_brick_road_the_compassion_deficit_debate_where_to_from_here, 24, 1445 - 1446. 
Dean, E. (2012). Dignity in toileting. Nursing Standard 26(24), 18 Henta frå https://search.proquest.com/docview/922566142/fulltextPDF/BE3226BE3D3496EPQ/1?accounti $\mathrm{d}=15685$

Demensplan. (2015). Demensplan 2020. Et mer demensvennlig samfunn. Henta frå https://www.regjeringen.no/contentassets/3bbec72c19a04af88fa78ffb02a203da/demensplan_2 020.pdf

Douglas, M. (1997/1966). Rent og urent: en analyse av forestillinger omkring urenhet og tabu. Oslo: Pax.

Dæhlie, K. (2006, s. 96 - 99). Vi kunne være renslige uten baderom : en studie av vann : personlig renslighet og modernisering i fjellbygda Alvdal Universitetet i Oslo.

Eek, E. \& Lunde, P. (2014). Fremtidens baderom på sykehus. Bergen: Helse Bergen HF, Bano AS, Innovest AS. Henta frå http://www.bano.no/pdf/FINAL\%20Bano\%20fremtidens\%20baderom_read_.pdf

Furu, B. (2008). Fremtidens eldreboliger. Toalettproblematikk for eldre og funksjonshemmede $i$ Trondhjem Trondheim kommune

Glatved - Prahl, H. (2015, 28.5.). Fant sønnen med brukket arm i sengen. Bergens Tidende.

Greed, C. (2004). Public toilets: The need for compulsory provision University of the West England, Bristol http://eprints.uwe.ac.uk/24155/1/muen157-077.pdf.

Guldbrandsen, O. \& Christophersen, J. (2011). Tilgjengelighet i nye boliger. Oslo: Byggforsk, Norges byggforskningsinstitutt. Henta frå https://evalueringsportalen.no/evaluering/universellutforming-og-tilgjengelighet-i-norsk-boligpolitikk/Uu_norsk\%20boligpolitikk.pdf/@@inline

Haagensen, V. W. $(2018,20.11$.). Fikk beskjed om å henge opp viltkamera på sykehjem. I H. o. O. NRK (Red.). Grue. Henta frå https://www.nrk.no/ho/uverdige-forhold-pa-sykehjem-1.14197366

Halskov, G., Lundin, S. \& Petersen, K. (2008). Homologier IK. Petersen \& M. Høyen (Red.), At sette spor på en vandring fra Aquinas til Bourdieu - æresbog til Staf Callewaert København: Hexis.

Hansen, J. A. (2009). Om feltanalytiske interwiews i analyser af aktivering. I O. e. a. Hammerslev (Red.), Refleksiv sociologi i praksis. København: Hans Reitzels Forlag.

Hauge, S. (2004). Jo mere vi er sammen, jo gladere vi blir? Institutt for sykepleievitenskap og helsefag, Universitetet i Oslo, Oslo.

Hofseth, C. \& Norvoll, R. (2003). Kommunehelsetjenesten - gamle og nye utfordringer. En studie av sykepleietjenesten i sykehjem og hjemmesykepleien. SINTEF forskningsrapport. Henta frå http://hdl.handle.net/11250/2467188

Holvik, M. G. (2018). Pårørende i sykepleiefaget - "Fra ansvarsfraskrivende slektning til samarbeidspartner" Distinksjonen mellom betalt og ubetalt hjelp til hjemmeboende eldre Universitetet i Bergen, Bergen. Henta frå http://bora.uib.no/bitstream/handle/1956/17896/Marianne-Giske-Holvik---P-R-RENDE-ISYKEPLEIEFAGET.pdf?sequence $=28$

Husbanken. (1961). Vedlegg til Husbankens årsmelding 1960. Årsstatistikk 1960. Oversikt over boligstandard, byggkostnader, finansiering på grunnlag av innvilga søknader. Oslo. Henta frå http://biblioteket.husbanken.no/arkiv/dok/2172/aas_1960.pdf

Husbanken. (2009). Rom for trygghet og omsorg. Henta frå http://biblioteket.husbanken.no/arkiv/dok/3488/nylink_rips.pdf 
Husbanken. (2020a). Omsorgsplasser i institusjon. I. Henta frå https://www.veiviseren.no/stotte-iarbeidsprosess/fremskaffe-og-forvalte-boliger/veileder-for-lokalisering-og-utforming-avomsorgsbygg/3-ulike-bo-og-aktivitetstilbud/omsorgsplasser-i-institusjon

Husbanken. (2020b). Veivisen for bolig og tjenesteområde. Livsløpsbolig. I: Husbanken. Henta frå https://www.veiviseren.no/stotte-i-arbeidsprosess/tilrettelegge-og-beholde-bolig/livslopsbolig

Isaksen, L. W. (1992). Kroppsnærheten førklarar omsorgsarbetets låga status. Kvinnovetenskaplig tidsskrift, 4, 14-19.

Kira, A. (1976). The bathroom. New York: Penguin Books.

Kiøsterud, T. W. (2016). Norsk boligpolitikk før og no. Plan, 3/4, 22 - 31. Henta frå https://www.idunn.no/file/pdf/66887400/norsk_boligpolitikk_foer_og_naa.pdf

Kjær, E. J. (2019, 11.3.). Afd $\varnothing$ d plejehjemsbeboer i åbent brev: Skal man planlegge toiletbes $\varnothing$ g efter bemandning? Jyllands-Posten, Indland. https://jyllands-posten.dk/indland/ECE11243445/afdoedplejehjemsbeboer-i-aabent-brev-skal-man-planlaegge-toiletbesoeg-efter-bemanding/.

Kristhoff, J. \& Andersen, K. (2016). Uformell omsorg til pasienter i hjemmesykepleien. Sykepleien forskning, 4(10), 362 - 370. Henta frå https://sykepleien.no/forskning/2015/11/uformell-omsorgtil-pasienter-i-hjemmesykepleien

Lawler, J. (1996). Bak skjermbrettene: sykepleie, somologi og kroppslige problemer. Oslo: Gyldendal. https://www.nb.no/items/URN:NBN:no-nb_digibok_2008072200017.

Lee-Treweek, G. (1997). Women, resistance and care: an ethnographic study of nursing auxiliary work. Work, Employment \& Society 11 (1), 47-63.

https://doi.org/https://doi.org/10.1177/0950017097111003

Lunde, P. (2010). Erfaringer med baderom på sykehjem - og fra sykehus. Oslo: Forflytningsteknikk AS Henta frå http://docplayer.me/252857-Erfaringer-med-baderom-pa-sykehjem-og-frasykehus.html.

Lundström, I., Hermansen, R. \& Kellmer, I.-H. (1978). Om renslighet: hygienen gjennom tidene $i$ Bergen Bergen: Bryggens museum.

Martinsen, K. (2003). Omsorg, sykepleie og medisin: historiske og filosofiske essays. Oslo: Universitetsforlaget.

Nettleton, S., Buse, C. \& Martin, D. (2018). Essentially it's just a lot of bedrooms': architectural design, prescribed personalisation and the construction of care homes for later life. Sociology of Health and IIIness, 40(7), 1156-1171. https://doi.org/doi: 10.1111/1467-9566.12747

Nightingale, F. (1997/1860). Notater om sykepleie. Oslo: Universitetsforlaget. Henta frå https://www.nb.no/items/02a96b4d13319d9ad0e8f5c25fb6d73f?page=0\&searchText=subjecttop ic:florence

Norredam, M. \& Album, D. (2007). Prestige and its significance for medical specialities and disease. Scandinavian Journal of Public Health, 35(6), 655-661

https://doi.org/https://doi.org/10.1080/14034940701362137

Prieur, A., Kristiansen, S. \& Jacobsen, M. H. (2002). "Liv, fortælling, tekst : strejftog i kvalitativ sociologi Aalborg: Aalborg Universitetsforlag.

Regjeringen. (2013). Morgendagens omsorg Oslo: Helse- og omsorgsdepartementet Henta frå https://www.regjeringen.no/en/dokumenter/meld.-st.-29-2012-2013/id723252/

Ruud, S. \& Dommerud, T. (2015, 11.9. ). Unødvendig mange eldre i sykehjem får beroligende medisiner Aftenposten. Henta frå https://www.aftenposten.no/norge/i/VPW6/unoedvendigmange-eldre-paa-sykehjem-faar-beroligende 
Schiøtz, A. (2003). Folkets helse - landets styrke, 1850-2003. Oslo: Universitetsforlaget.

Siegumfeldt, B. (1992). Renhed og rammer. København: Institutt for Pædagogik. Københavns Universitet.

Sintef. (2020). TEK-17. I: Sintef. Henta frå https://www.byggforsk.no/byggeregler

Stacey, C. L. (2005). Finding dignity in dirty work: the constraints and rewards of low-wage home care labour. Socioeconomic Issues of Health, 27(6), 831-854

https://onlinelibrary.wiley.com/doi/pdf/810.1111/j.1467-9566.2005.00476.x.

Sundt, E. (1975/1869). Om renligheds-stellet i Norge. Oslo: Gyldendal.

Sydnes, T. (2001). Centrale ideer i Florence Nightingales sykepleiefilosofi /Cental ideas in Florence Nightingales nursing philosophy. I R. Birkelund (Red.), Omsorg, kald og kamp. Personer og ideer $i$ sykepleiens historie. København: Gyldendal.

Twigg, J. (2000). Bathing, the body and community care. London: Routledge

Vangsnes, E. M. B. (2003). Heilt andre tider. Fusa 1900 - 2000, Band I. Fusa: Fusa kommune.

Vangsnes, E. M. B. (2005). Heilt andre tider. Fusa 1900 - 2000, Band III. Fusa: Fusa kommune.

$\varnothing$ kland, B. G. (2000). Bare boss? Bergen: Bryggens museum.

Ågotnes, G., Lea, K. \& Petersen, K. A. (2019). Reflections on interviews: Official accounts and social asymmetry. Praktiske Grunde. Nordisk tidsskrift for kultur- og samfundsvidenskab, 1-2, s. 207 219. Henta frå http://praktiskegrunde.dk/2019/praktiskegrunde(2019-1+2z)samlet.pdf 